\title{
IMPACT OF ASIAN FINANCIAL CRISIS ON MALAYSIAN CORPORATE REAL ESTATE DISPOSALS
}

\author{
TING KIEN HWA \\ Universiti Teknologi MARA
}

ANNUAR MD NASSIR

Universiti Putra Malaysia

\author{
GRAEME NEWELL \\ University of Western Sydney
}

and

\author{
TAUFIQ HASSAN \\ Universiti Putra Malaysia
}

\begin{abstract}
This study examines the stock price reactions to the announcements of corporate real estate disposals by listed non-property companies in Malaysia and whether disposals under different economic conditions lead to different price reactions. The results show that the cumulative abnormal returns associated with the property disposals differ significantly in different economic conditions. Price reaction for property disposals before the Asian financial crisis is consistent with the normal investor expectations of increasing shareholder value. However, property disposals during and after the crisis have negative wealth effects. Cross-sectional regressions show that the Asian financial crisis and the relative size of the disposal are significant factors affecting the abnormal returns. The findings extend the literature on corporate real estate disposal by concluding that price reactions are conditional on economic conditions at the time of announcements on property disposals.
\end{abstract}

Keywords: Corporate real estate, disposals, event study, wealth effects 


\section{INTRODUCTION}

Divestitures of corporate real estate are a significant corporate reorganisation activity. Past studies document significant positive abnormal stock price reactions to sellers on announcements of property disposals (Owers and Rogers, 1986; Glascock et al., 1991; Liow, 1997). The evidence in these studies is based on property disposals in developed countries (i.e. USA and UK) made in the 1970s and 1980s.

Corporate real estate refers to the land and buildings owned by companies not primarily involved in the real estate business (Zeckhauser and Silverman, 1983). Corporate real estate is a significant asset in the balance sheets of Malaysian listed non-property companies. For the year 2001, the total real estate owned by a selected 500 non-property companies amounted to RM96.27billion representing $20.7 \%$ of the total market capitalization (RM465 billion) of Bursa Malaysia and it constitutes about $24 \%$ of the total tangible assets of these firms (Ting , 2004).

The average value of properties owned by a listed non-property company for the 19952001 period is RM137 million. For the same period, on average, real estate comprises $36 \%$ of net tangible assets, $34 \%$ of shareholders' equity, $35 \%$ of market capitalization, $27 \%$ of total capital employed and $19 \%$ of total tangible assets of listed non-property companies for the 1995-2001 period (Ting, 2004).

For the first half of 1990s, the Malaysian economy has experienced strong economic growth and high asset inflation. With massive inflows of foreign direct investments into the country, the real estate market has been buoyant. Initial yields of prime properties are low due to investors' expectations of potential capital growth. Given the focus on capital growth, the real estate returns have become more volatile.

However with the onset of the Asian Financial Crisis in 1997, the property market was badly affected by the significant devaluation of Ringgit, the flight of foreign capital, financial distress of financial institutions, deterioration in employment and economic conditions. During the initial stage of the crisis, lending to the property sector was severely curtained by strict lending policies imposed by Bank Negara Malaysia (BNM) to a limit of $20 \%$ of the total outstanding loans. The margin of lending has been reduced to $60 \%$ maximum margin of financing. Banks are not allowed to finance the development of residential properties and shophouses more than RM250,000, the development of hotels, resorts, office buildings, golf courses and shopping complexes. The restriction on the provision of bridging finance for residential properties are lifted only in November 2001.

The Asian Financial Crisis has escalated the volatility of real estate returns in the country. Real estate is found to play a major role in the economic crises of emerging countries (Mera and Renaud, 2000). Asian firms particularly those in the emerging 
countries are more exposed to real estate than other countries in the United States of America, United Kingdom and Europe (Liow and Ooi, 2004).

This study will provide a better understanding on the returns behaviour of shares on corporate real estate transactions in different phases of the economic cycle of a developing country, particularly during a financial crisis.

Disposals are the sales of some segments of a company to a buyer. The transaction may entail some operating assets (e.g. property), product lines, divisions or subsidiaries to the buyer. In exchange, the buyer will pay cash, shares or any other forms of compensation.

In the case of corporate real estate, a divestiture transaction could be a single property, a property portfolio, a business unit, division or subsidiary owning properties. Corporate real estate which provides the manufacturing space, office, marketing and production space are often divested together with the business unit. The firms generally use the divestiture proceeds to invest in other business segments, reduce borrowings, repurchase outstanding shares of capital stock or distribute a dividend to shareholders.

Divestitures also play a significant role in the business life cycle of a firm, particularly during the maturity phase where operations are discontinued due to withdrawal from a particular market (e.g. cessation of business or operations), consolidation of operations (e.g. when scattered facilities are consolidated into fewer modern premises) and liquidations (Giroux, 1987). Tough economic conditions and business environment are often the causes that lead to discontinued operations.

\section{OBJECTIVES AND SIGNIFICANCE OF THE STUDY}

Real estate is a significant factor in the Asian Financial Crisis (Mera and Renaud, 2000). This study extends the existing literature on corporate real estate disposal by examining the impact of economic conditions on the stock price reactions to corporate real estate disposal announcements. This study updates and refines the limited research on disposal of corporate real estate and thus enriches the few empirical evidences.

The primary objective of this study is to examine the share price reactions to corporate real estate disposals by non-property companies for the January 1992 to December 2001 period. This study period is chosen as it coincides with a complete economic and property cycles of boom and bust in Malaysia. This avoids the study to be biased towards a particular phase of the cycles. The study is further divided into two sub-periods: (a) 1992-1996 period which is characterized by strong economic growth and high asset inflation; and (b) 1997-2001 period which reflects financial crisis, economic recession and recovery phase of the markets after the Asian Financial Crisis. The existence of financially distressed listed companies and the high non-performing loans (NPL) of financial institutions after the crisis (1997-1999) provides another basis for these two sub-periods. 
The second objective is to examine whether the cumulative abnormal returns are significantly different for the two economic periods. Thirdly, to examine the source of gains/loss to the cumulative abnormal returns.

\section{LITERATURE REVIEW}

The literature on divestiture has generally established that when firms divest assets, the sellers would enjoy positive abnormal gains. The supporting evidence on positive disposal gains are Alexander, Bensen and Kampmeyer (1984), Boudreaux (1975), Hearth and Zaima (1984), Jain (1985), Klein (1986), Linn and Rozeff (1984) and Zaima and Hearth (1985). Positive stock reactions on spin-offs are reported by Hite and Owers (1983), Linn and Rozeff (1984), Miles and Rosenfeld (1983) and Schipper and Smith (1983). Other forms of divestiture also report positive gains such as equity carve-outs (Schipper and Smith, 1986) and liquidations (Elayan and Maris, 1991).

For the disposal of real estate by conventional firms, it is also generally established that sellers of real estate assets enjoy significant wealth effects on the announcements of property disposals. On the disposal of real estate assets, Owers and Rogers (1986) find significantly positive abnormal returns of about $2 \%$ for fifty-five sellers. Glascock, Davidson and Sirmans (1991) find the stock price reaction of about 1\% for fifty-one sellers to be significant positive (refer Table 1). Using a GARCH model, Booth, Glascock and Sarkar (1996) report significant positive abnormal returns for thirty-seven sellers.

For the spin-offs of real estate subsidiaries, Hite, Owers and Rogers (1984) and Ball, Rutherford and Shaw (1993) find significantly positive abnormal returns for the sellers' shareholders.

It is noted that past studies on property disposals are dated and focused on developed markets. This study updates and covers both a buoyant and recession period in a developing country. This will be the first study examining the impact of the crisis on the disposal of properties by non-property companies in the property market before and after the crisis. This study is motivated by the absence of evidence on stock price reaction of property disposals under different economic conditions.

The hypothesis for disposals under the buoyant economic condition is significant positive stock reactions and for the recession condition significant negative stock reactions on the announcement of property disposals.

Rationales for differing stock price reactions towards property disposals during different economic conditions include: 
Table 1 : Empirical evidence on real estate disposals by non-property companies

\begin{tabular}{|c|c|c|c|}
\hline Authors & $\begin{array}{c}\text { Sample } \\
\text { period and } \\
\text { Size } \\
\end{array}$ & $\begin{array}{l}\text { Abnormal } \\
\text { return }\end{array}$ & Summary of findings \\
\hline $\begin{array}{l}\text { Owers and Rogers } \\
\text { (1986) }\end{array}$ & $\begin{array}{l}1968-1981 \\
55\end{array}$ & $\begin{array}{l}0.70 \% \\
(-1,0)\end{array}$ & $\begin{array}{l}\text { On average, sell-offs are } \\
\text { associated with statistically } \\
\text { significant positive abnormal } \\
\text { returns for both the selling and } \\
\text { acquiring firms. }\end{array}$ \\
\hline $\begin{array}{l}\text { Glascock, Davidson } \\
\text { and Sirmans (1989) }\end{array}$ & $\begin{array}{l}1985-1986 \\
9 \\
\end{array}$ & $\begin{array}{l}3.41 \% \\
(-5,-1) \\
\end{array}$ & $\begin{array}{l}\text { Evidence of a weak positive } \\
\text { market reaction is found. }\end{array}$ \\
\hline $\begin{array}{l}\text { Glascock, Davidson } \\
\text { and Sirmans (1991) }\end{array}$ & $\begin{array}{l}1971-1986 \\
51\end{array}$ & $\begin{array}{l}1.23 \% \\
(-1,+1)\end{array}$ & $\begin{array}{l}\text { Statistically significant } \\
\text { positive returns on the } \\
\text { announcement of sale of real } \\
\text { properties. Significant gains } \\
\text { for sellers but not for the } \\
\text { acquiring firms. }\end{array}$ \\
\hline Liow (1997) & $\begin{array}{l}1982-1991 \\
67\end{array}$ & $\begin{array}{l}0.98 \% \\
(0,0)\end{array}$ & $\begin{array}{l}\text { Statistically significant } \\
\text { positive returns. }\end{array}$ \\
\hline
\end{tabular}

\section{Buoyant economic conditions}

Information asymmetry

One of the reasons for positive market reactions on property divestitures is information asymmetry (Owers and Rogers, 1986). Over the long run, properties increase in capital value over time. However, under the modified historical cost accounting convention, real estates are reported in the balance sheets at historical cost or values determined during the last revaluation. Property revaluations are not carried out in a frequent manner causing an information asymmetry situation. At the time of property divestiture announcements, information is disclosed on the value of the property assets. This enables the market to accurately price the property assets. During disposals, there is further information disclosure (e.g. details on properties and valuations) on book and market values of the assets owned by the firms which could help investors in evaluating the value of the firm.

Tax gains

Another reason for the gains in property divestiture is tax gains. A company may sell a property that has been fully depreciated under the allowable accounting policy/standard 
and repurchase another asset so that the depreciation benefits can be enjoyed again (Owers and Rogers, 1986; Glascock, Davidson and Sirmans, 1991). A company may continue to keep a fully depreciated asset if the operational advantages are greater than the new depreciation tax benefit.

\section{Negative synergy}

Divestiture can be used as a means to eliminate negative synergies (Owers and Rogers, 1986). Companies gain by disposing properties which do not fit with their business operations as the company would not be able to optimize the value of the property assets. On the other hand, a buyer may benefit from a better fit between the purchased asset and the buyers operation which is able to maximize the value of the property through its use.

A divestiture happens when the seller finds that the net sale proceed exceed the present value of the net future net cash flow from the asset. A buyer would be willing to buy if the buyer could put the asset to more efficient use (Jain, 1985; Sicherman and Pettway, 1992). As divestiture allows a less efficiently managed property to be transferred to another firm that can manage the asset more efficiently, these divestiture activities would improve aggregate economic activities.

\section{Focus hypothesis}

Under the focusing hypothesis, the seller gains if the divestiture results in a better focus of seller's business and thereby making the firm operate more efficiently by reducing its degree of diversification (John and Ofek, 1995). The positive wealth effect of real estate divestitures are consistent with the hypothesis that firm values increase when real estate assets are realigned to business requirements and inefficiently utilised real estate assets are disposed off. The available capital can then be utilised for higher return business activities.

\section{Recessionary economic conditions}

\section{Poor property market prospects}

During the crisis, the net operating income of investment properties will fall as demand for commercial space drops and net absorption rates decrease sharply. In the early stages of the Asian financial crisis which is a combined currency and banking crises, the interest rate rise sharply as the central bank apply high interest rate policy to defend currency and to slow capital outflows. The growth rate in net operating income declines while the risk premium rises sharply reflecting the higher returns required by investors to balance the higher risk (Fisher, 2000). Under the Gordon discounted dividend valuation framework, capital values can fall sharply and below replacement costs in the aftermath of a crisis.

For the property development sector, property owners are motivated by the buoyant property market prior to the crisis. Combined with the ownership of significant development land and their overconfidence have led property owners to jump into the 
development bandwagon (Wang et al., 2000). The immature real estate market infrastructure has delayed providing public access to reliable market supply and demand information. The lack of transparency in the real estate market, further hampered information flow in the property market.

\section{Lower expected profitability}

In response to the Asian financial crisis, the initial government policy responses from July 1997 to June 1998 had introduced tight fiscal policy and increased interest rates. Both measures have caused aggregate demand in the economy to contract causing a deep recession.

The increase in interest rates causes borrowers to make higher repayments and face rising debt obligations. The cost of imported inputs rises in tandem with high foreign exchange rate for the Ringgit. Construction projects with high import content are adversely affected and are deferred indefinitely.

With recession, the unemployment rate started to increase and consumer sentiments turned bad. The collapse of the stock market further worsened the negative wealth effect. Banks became more cautious in extending new loans causing loan growth to decrease significantly reducing from 26.5 per cent in 1997 to 1.8 per cent in 1998 . With poorer economic conditions, more companies suffered cash-flow problems and more loans turned bad. The non-performing loan ratio doubled from 4.1 per cent in 1997 to 9.0 per cent in 1998.

Dranikoff et al. (2002) noted that divestitures are often made after long delays and under strained circumstances; e.g. heavy losses and heavy debt burden at fire-sale prices. Thus there is a strong bias against divestiture as the action signal weakness and even failure of the firm. This negative perception is further compounded during a crisis/recession period where profits are declining and the business environment is getting increasingly difficult.

\section{Decreased opportunities in diversification}

Kallberg, Liu and Pasquariello (2002) reported structural breaks in the returns and volatility of the Asian equity and real estate market during the 1997 to 1998 period. The impact of the crisis on the real estate market is to reduce the real estate returns and increase real estate volatility. The correlation between real estate and other asset classes has also increased during the financial crisis. As a result, there is a decrease in diversification opportunities.

Property disposal is a more viable option to improve cashflow

A highly leverage firm with cashflow problems may have the options of debt rescheduling, issue new securities or asset sell-offs. During the financial crisis, debt rescheduling might be costly and difficult to be achieved since it requires the approval from multiple creditors (Gertner and Scharfstein, 1991). As managers may take extra risks if the loan maturities are extended, creditors are not in favour of rescheduling in the 
face of uncertainty on future investment prospects and profitability (Jensen and Mackling, 1976). New security issues might also face difficulty due to uncertainty of new security buyers about the value of the firm and the quality of management (Myers and Majluf, 1984). The asymmetric information problem will increase the cost of security issues.

Compared to debt rescheduling and new securities issue, asset sales are the most attractive choice for the firms, as asymmetric information is likely to be lesser. Asset sales can reduce the conflicts between creditors, reduce the asset substitution problem, control agency costs and alleviate the informational symmetry between the firm and outsiders. Asset sales such as property disposals become the preferred choice during the financial crisis.

Announcements that reveal negative information about the cash flows of the real estate components of a company will decrease the market's expectations of the profitability of the firm.

\section{Lesser potential property buyers}

Compared with other assets of a firm such as patents and brand name, real estate is a more liquid and deployable asset. The highest bid possible for the property depends on the type of buyers. Basically, there are three types of potential buyers. The first type of buyers is those from other firms in the same industry. Due to the related nature of the assets, the buyer is likely to be able to make the best offer in their valuation of the asset (Brown et al., 1993).

However during the financial crisis, the distress is likely to be industry and economy wide. With the credit crunch during the crisis, the industry buyers will also have difficulty to raise funds. Thus assets would have to be sold to industry outsiders. A fairly modern and adaptable manufacturing/industrial facility will still have a fair chance of finding a buyer.

But for specialized properties, the industry outsiders will face adverse selection and moral hazard problems about the quality of the corporate real estate asset. As a result, the offer price from the outsider will most likely to be lowest.

The third category of buyers is the neighbouring property owners. Such owners are likely to enjoy marriage value which will be a positive net present value transaction (Baum, 1983; Baum, Mackmin and Nunnington, 1997). The offer price will be higher than the industry outsiders but lower than the industry buyers.

\section{Information asymmetry and the property market}

Under the asset information hypothesis, investors pay particular attention to corporate and economic events that reveal information about the value of these assets. The basic hypothesis is that since real estate assets are traded infrequently, the market has 
incomplete information about their true value. Couple with the fact that property assets in a company are seldom revalued on a frequent basis, the lack of a timely and accurate public dissemination of information on real estate market conditions has led to information asymmetry. The lack of transparency led to increased costs of transactions. Renauld (2003) noted that emerging markets have immature property markets dominated by irrational pricing due to limited reliable information on the property market conditions. A better information system can improve price discovery and lower the costs of transaction.

Since a divested property is a stand alone entity, more information about the divested property is made available to the stock market when announcement is made. Thus the property will be valued higher when disposed during normal economic conditions. But during the crisis/recession period, the lack of property transactions increase information asymmetry. Coupled with the perception that disposals are often made under strained financial situations, property sell-offs will attract negative evaluation by investors thereby eliciting a negative stock price reactions.

\section{RESEARCH DESIGN}

\section{Data and sample selection}

This study covers Main and Second Board companies of Bursa Malaysia but excluding companies in the Property Trusts and Property Sector. The data were pooled across two sub-periods i.e. 1992-1996 pre-crisis period and $1997-2001$ post crisis period. The two periods correspond to different property market conditions of pre and post Asian financial crisis periods. The pooling helps to control for the performance of the property market and the inter-temporal instability in economic conditions.

The corporate real estate disposal announcement dates and details are obtained manually from the KLSE Dairy Daily (1992 to 1998) and Bursa Malaysia web-site under the "Listed Companies Announcements" web-page (1999 to 2001).

A total of 424 disposal announcements were obtained and only 128 announcements are selected for the event study after meeting the following criteria:

(a) The corporate real estate announcements are made between 1992 to 2001;

(b) Announcements in the window period are without any confounding events such as rights and bonus issues, dividends and earnings announcements etc.;

(c) Each company has five years of continuous stock price for the estimation period to allow for the estimation of the market model parameters of $\alpha$ and $\beta$;

(d) Announcements by financially distressed companies that are classified under Practice Note 4 (PN4) are excluded. 
Table 2 shows the frequency distribution of the announcements by year. The distributions of the events are not clustered in time and are distributed quite evenly across the sample period.

\section{Table 2 : Distributions of property disposals by year}

\begin{tabular}{lccc}
\hline Year & $\begin{array}{l}\text { No. of } \\
\text { announcements }\end{array}$ & $\begin{array}{l}\text { No of selected } \\
\text { sample ann. }\end{array}$ & $\begin{array}{c}\text { Percentage } \\
(\%)\end{array}$ \\
\hline 1992 & 49 & 7 & 14.3 \\
1993 & 39 & 14 & 35.9 \\
1994 & 32 & 9 & 28.1 \\
1995 & 62 & 15 & 24.2 \\
1996 & 52 & 13 & 25.0 \\
1997 & 47 & 13 & 27.6 \\
1998 & 33 & 10 & 30.3 \\
1999 & 29 & 12 & 41.4 \\
2000 & 35 & 18 & 51.4 \\
2001 & 46 & 17 & 36.9 \\
\hline Total & 424 & 128 & \\
\hline
\end{tabular}

Table 3 shows that the sample includes a wide range of companies in various sectors and reflects the sector composition of the stock market

\section{Event study methodology}

Event study is a widely accepted approach to study the impact of an event on share prices in real estate, finance, economics and accounting. This approach is commonly used in examining various corporate real estate activities such as acquisitions, disposals, mergers, joint ventures and spin-offs (Rodriguez and Sirmans, 1996). Whilst other methods have been used to model and analyse the residuals (e.g. GARCH model), the overall results are identical (Booth, Glacock and Sarkar, 1996).

Bursa Malaysia being an emerging stock market suffers from low relative trading frequency; i.e. thin trading of listed shares. Thin trading causes a non-synchronous trading problem of underestimating beta and returns of a thinly traded stock whilst an actively traded stock will have overestimated beta and returns. 
Table 3: Sample distribution by sectors of Bursa Malaysia: 1992 - 2001

Sector

No. of disposal

announcements

Consumer

17

Industrial

Trading

Construction

Finance

Hotel

Plantation

Mining

Second Board

Total

128

Past studies on Bursa Malaysia have corrected the non-synchronous bias in beta using Fowler-Rorke estimator for two periods of lead-lag between stock returns and market returns (Ariff and Johnson, 1990; Annuar, Ariff and Shamsher, 1994; Cheng, 2000). The Fowler-Rorke procedure is also used in this study to obtain an unbiased estimate of the systematic risk. It is found that the two leads and two lags model gives an unbiased beta which has an average value closest to one.

To calculate the normal returns, a market model based on the capital asset pricing model was estimated over a five period before the announcement date. The Kuala Lumpur Composite Index (KLCI) is used in the market model. For the event study, the abnormal returns obtained for each company in the sample were aggregated in the form of average abnormal returns (ARs). To take into account the lengthy negotiation phase of property transactions, a long pre-announcement window period is used to capture any leakage of information. Thus the ARs were cumulated (CARs) over a window period of $(-50,+30)$. Statistical tests (t-tests) were conducted for these ARs and CARs to assess the statistical validity of stock reactions to property disposal announcements. 


\section{Models for source of wealth gain}

A cross-sectional regression analysis is carried out to check the factors that are significant to the disposal and to note the signs of the coefficients.

A dummy variable is included to control for any regime shifts in the economic conditions following the financial crisis. The variable takes the value of one for event announcements on and after 1997 and zero otherwise. The dummy variable is expected to have negative impact on the risk adjusted returns of stocks.

Firms that divest with a capital gain from its property disposal would be favourable to shareholders wealth. Hence we hypothesized that abnormal returns would depend on whether capital gains are made from the transaction. The expected sign of the coefficient is expected to be positive as gains have been found to increase shareholder returns. Disposal gain takes a value of one if there is a capital gain and zero for disposal with loss.

An agency problem will arise if properties are transacted between related parties resulting in non-arms length transaction. Poor quality properties or distressed properties might be injected into another related company. The hypothesis formed is that abnormal returns depend on whether the transactions are related or an arms length transaction. The expected sign of the coefficient is expected to be negative if the transaction is related. If the transaction is between related parties, the RELATED variable will be one and zero otherwise.

Firms that dispose relatively large parts of their business generate larger shareholder value gains (Klein, 1986). This suggests a substantial property disposal is favoured by investors. Thus the larger the size of disposal the bigger the stock price reactions. The expected sign of the coefficient is expected to be positive, as large gains have been found to increase shareholder returns.

To examine factors that may contribute to the CAR of divestiture, the following crosssectional models are used :

MODEL 1

$\overline{\text { CARDISP }_{\mathrm{i}}}=\alpha_{\mathrm{i}}+\beta_{\mathrm{i} 1} \mathrm{ECON}+\beta_{\mathrm{i} 2} \mathrm{SIZE}+\varepsilon_{\mathrm{i}}$

where:

CARDISP $_{\mathrm{i}}=$ the dependent variable of the three day announcement CAR $(-1,+1)$ for each selling firm

$\mathrm{ECON}=$ coded as one if the transaction announcement is from 1997 to 2001, or zero otherwise

$\mathrm{SIZE}=$ the relative value of property disposed to market capitalization of firm

$\varepsilon_{\mathrm{i}}=$ error term. 
MODEL 2

CARDISP $_{\mathrm{i}}=\alpha_{\mathrm{i}}+\beta_{\mathrm{i} 1}$ ECON $+\beta_{\mathrm{i} 2}$ GAIN $+\beta_{\mathrm{i} 3}$ RELATED $+\varepsilon_{\mathrm{i}}$

where:

CARDISP $_{\mathrm{i}}=$ the dependent variable of the three day announcement CAR

$(-1,+1)$ for each selling firm

$\mathrm{ECON}=$ coded as one if the transaction announcement is from 1997 to 2001, or zero otherwise

GAIN= a dummy variable that takes the value of one if the disposal is a capital gain or zero otherwise

RELATED $=$ coded as one if the transaction is related or zero otherwise

$\varepsilon_{\mathrm{i}}=$ error term.

\section{RESULTS}

Table 4 shows the various reasons for property disposals. The table shows contrasting reasons for undertaking property disposals during the two economic periods. Disposals aimed at reducing borrowings are higher at $38.3 \%$ during the recession period compared to $25.5 \%$ during the buoyant period. Prior to the recession period, there is no disposal aim to obtain additional working capital, as compared to $8.6 \%$ during the recession period. Also a higher percentage of property sell-offs are carried out to dispose off surplus properties and to streamline their operations during the recession period. During the crisis, lesser disposals are made to realize investment gains.

Table 4: Reasons for property disposals

\begin{tabular}{lcll}
\hline & $1992-1996$ & $1997-2001$ & $1992-2001$ \\
\hline Reduce borrowings & 12 & 31 & 43 \\
& $(25.5 \%)$ & $(38.3 \%)$ & $(33.6 \%)$ \\
Additional working capital & 0 & 7 & 7 \\
& $(0 \%)$ & $(8.6 \%)$ & $(5.5 \%)$ \\
Surplus/streamline operations & 6 & 15 & 21 \\
& $(12.8 \%)$ & $(18.5 \%)$ & $(16.4 \%)$ \\
Realise investment gains & 10 & 10 & 20 \\
& $(21.3 \%)$ & $(21.3 \%)$ & $(15.6 \%)$ \\
No reasons given & 19 & 18 & 37 \\
& $(40.4 \%)$ & $(22.2 \%)$ & $(28.0 \%)$ \\
\hline & 47 & 81 & 128 \\
& $(100 \%)$ & $(100 \%)$ & $(100 \%)$ \\
\hline
\end{tabular}

Pacific Rim Property Research Journal, Vol 12, No 1 
Table 5 shows the descriptive statistics of the disposals for the two study periods. The average and median values of the properties disposed are higher for the pre-crisis period. The distribution of the values of the properties disposed show a higher kurtosis and skewed property values for the recession period.

Table 5: Descriptive statistics of the values of the properties disposed

\begin{tabular}{llll}
\hline & $1992-1996$ & $1997-2001$ & $1992-2001$ \\
\hline Mean & $58,429,065$ & $56,560,683$ & $57,443,685$ \\
Median & $21,500,000$ & $15,288,000$ & $16,031,778$ \\
Mode & $33,000,000$ & $45,000,000$ & $30,000,000$ \\
$\begin{array}{l}\text { Standard } \\
\text { deviation }\end{array}$ & $84,865,931$ & $138,137,468$ & $115,672,170$ \\
Kurtosis & 8.967 & 20.453 & 22.612 \\
Skewness & 2.606 & 4.227 & 4.191 \\
Minimum & 200,000 & 274,646 & 200,000 \\
Maximum & $483,185,380$ & $900,000,000$ & $900,000,000$ \\
Sum & $4,031,605,455$ & $4,355,172,616$ & $8,386,778,071$ \\
\hline
\end{tabular}

\section{Revaluation effect of property disposals (1992-2001)}

Table 6 summarized the daily average abnormal returns (ARs) and cumulative abnormal returns (CARs) for the property disposals. The day zero average abnormal return is about $-0.05 \%$, but is statistically insignificant at any level. The ARs on day -45 , day -35 , day 29 are significantly different from zero at 0.05 level. Day -26 is significantly different from zero at 0.01 level. The statistically significant ARs observed before the announcement date might be due to leakage of information on the property transaction. After the announcement date, only day 15 is significantly different from zero at the 0.05 level. 
Table 6: Average Abnormal Returns on Property Disposal Announcements of Bursa Malaysia Listed Non-property Firms from 1992 to 2001

\begin{tabular}{|c|c|c|c|c|}
\hline & $\begin{array}{r}\text { Average } \\
\text { Returns } \\
\end{array}$ & t-test & & CAR \\
\hline-50 & -0.001809 & -0.602478 & & -0.001809 \\
\hline-45 & 0.007001 & 2.104314 & $*$ & -0.006427 \\
\hline-35 & -0.006949 & -2.157462 & $*$ & -0.021787 \\
\hline-30 & 0.000778 & 0.252598 & & -0.022176 \\
\hline-29 & -0.006530 & -2.090930 & $*$ & -0.028706 \\
\hline-28 & 0.000446 & 0.139240 & & -0.028260 \\
\hline-27 & -0.003856 & -1.269345 & & -0.032116 \\
\hline-26 & -0.008381 & -2.743179 & $* *$ & -0.040497 \\
\hline-25 & 0.004160 & 1.316246 & & -0.036337 \\
\hline-24 & -0.005272 & -1.758501 & & -0.041609 \\
\hline-23 & 0.000032 & 0.011529 & & -0.041577 \\
\hline-22 & 0.001301 & 0.293477 & & -0.040276 \\
\hline-21 & -0.000753 & -0.179266 & & -0.041029 \\
\hline-20 & -0.006048 & -1.611772 & & -0.047077 \\
\hline-10 & -0.003377 & -1.553603 & & -0.067310 \\
\hline-9 & 0.000003 & 0.000972 & & -0.067307 \\
\hline-8 & -0.003545 & -1.332567 & & -0.070853 \\
\hline-7 & -0.002950 & -1.118392 & & -0.073802 \\
\hline-6 & 0.004896 & 1.554544 & & -0.068906 \\
\hline-5 & -0.004755 & -1.376142 & & -0.073661 \\
\hline-4 & -0.004161 & -1.190112 & & -0.077822 \\
\hline-3 & 0.000963 & 0.304646 & & -0.076859 \\
\hline-2 & 0.000813 & 0.243081 & & -0.076046 \\
\hline-1 & 0.004253 & 0.856423 & & -0.071793 \\
\hline 0 & -0.000500 & -0.090959 & & -0.072293 \\
\hline 1 & 0.001387 & 0.420682 & & -0.070905 \\
\hline 2 & -0.001994 & -0.616140 & & -0.072899 \\
\hline 3 & -0.000658 & -0.193382 & & -0.073558 \\
\hline 4 & -0.002818 & -0.932804 & & -0.076376 \\
\hline 5 & 0.001413 & 0.429890 & & -0.074963 \\
\hline 6 & 0.003783 & 1.055237 & & -0.071180 \\
\hline 7 & -0.003753 & -1.043059 & & -0.074933 \\
\hline 8 & -0.001423 & -0.406824 & & -0.076356 \\
\hline 9 & 0.002510 & 0.737942 & & -0.073846 \\
\hline 10 & -0.002460 & -0.794335 & & -0.076306 \\
\hline
\end{tabular}




\begin{tabular}{lrrr}
11 & -0.004660 & -1.462614 & -0.080967 \\
12 & 0.003074 & 0.851209 & -0.077893 \\
13 & 0.000334 & 0.123624 & -0.077559 \\
14 & 0.000080 & 0.022947 & -0.077479 \\
15 & 0.006511 & $2.332038 *$ & -0.070968 \\
16 & 0.005240 & 1.263504 & -0.065728 \\
17 & -0.002342 & -0.678082 & -0.068070 \\
18 & 0.003690 & 1.072054 & -0.064380 \\
19 & 0.001264 & 0.362470 & -0.063117 \\
20 & -0.001833 & -0.544039 & -0.064950 \\
30 & -0.003936 & -1.047483 & -0.076232 \\
\hline
\end{tabular}

Note: Significant at $0.05(*)$ and $0.01(* *)$ levels.

Figure 1 presents the plot of CAR around the property disposal announcement day. Overall, the cumulative abnormal returns for the whole study period have negative values and trend in a downward direction. On the announcement date, the CAR is a loss of $7.23 \%$ to shareholders. This result is contrary to conventional wisdom that sell-offs are significantly positive to shareholders wealth. Studies by Owers and Rogers (1986), Glascock, Davidson and Sirmans (1991) and Liow (1997) have shown that property disposals are positive corporate actions that bring forth positive price reactions.

To examine the effect of economic conditions on the stock price reactions, the study period is split into buoyant period (1992-1996) and recession period (1997-2001). The results are discussed in the following sections.

\section{Revaluation effect of property disposals during the buoyant period (1992-1996)}

Table 7 summarized the daily average abnormal returns (ARs) and cumulative abnormal returns (CARs) for the 1992-1996 period. The day zero average abnormal return is $-0.498 \%$ but is statistically insignificant at any level. The average abnormal return for the window $(-1,+1)$ is $0.759 \%$ which is comparable in magnitude with similar studies in USA (Owers and Rogers, 1986) and in UK (Liow, 1997).

The day zero average abnormal return is not statistically significant. But before the announcement day, the abnormal return on day -40 , day -17 and day -6 are significantly different from zero at the 0.05 level. The explanation could be due to leakage of information occurring before the announcement date. The information leakage explains why the average abnormal return is not significant on the announcement day. 
Figure 1: Plot of Cumulative Abnormal Returns Around Property Disposal Announcements on Bursa Malaysia from 1992 to 2001

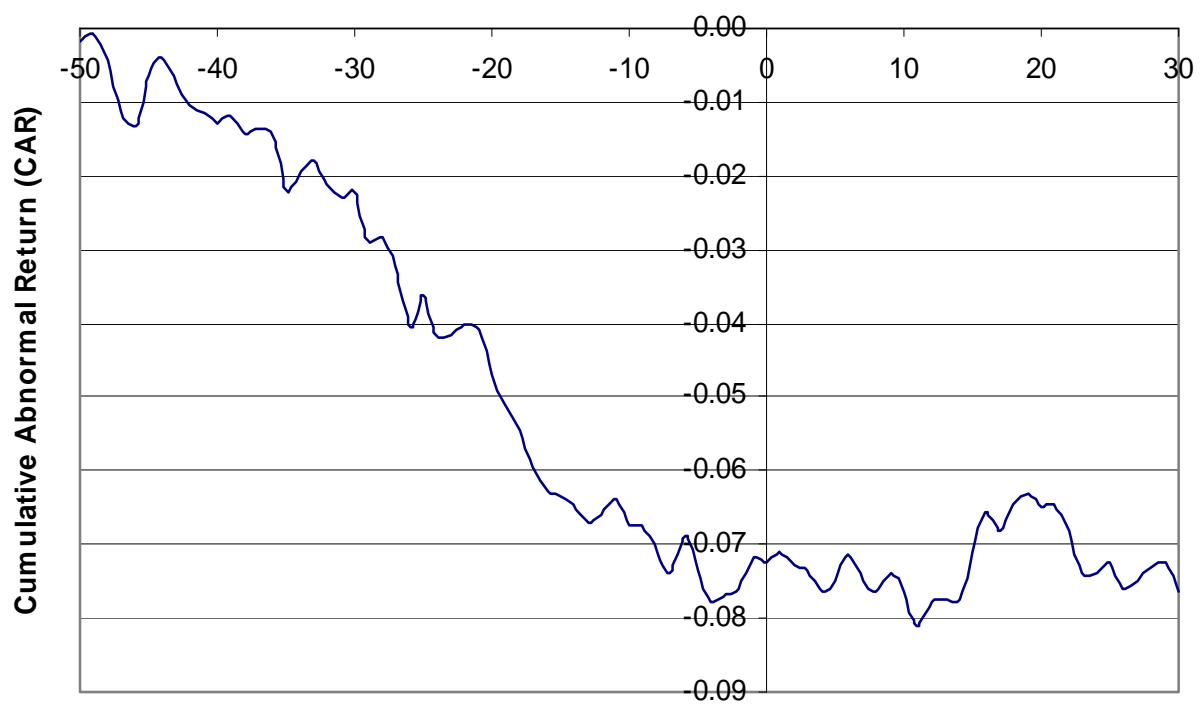

Day relative to Announcement Day (Announcement day $=0$ day)

After the announcement day, day +16 , day +26 and day +28 are significantly different from zero at the 0.05 level. The market seems to take some time before disposal information is fully impounded into the share prices. One possible reason is that additional information on the property disposal is released into the market after the announcement date. Investors constantly monitor and evaluate these information that flow into the market over time.

Figure 2 presents the plot of CAR around the property disposal announcement day. Overall, the CARs for the 1992-1996 period have positive values and trend in an upward direction. This result is consistent with previous studies.

Table 8 shows the CARs over different cumulative periods. The CAR value for the (-1, +1 ) is significantly different from zero at the 0.01 level. The CARs are positive and statistically insignificant before the announcement day, but are positive and statistically significant at 0.05 level for the post announcement window of $(+2,+10),(+2,+20)$ and $(+2,+30)$. Investors continue to monitor and evaluate new information after the announcement day. 
During the buoyant period, investors appear to respond positively to the announcement of property disposals. The overall results seem to support the hypothesis that property disposal during the buoyant economic period are net positive value transactions.

Table 7: Average Abnormal Returns on Property Disposal Announcements of Bursa Malaysia Listed Non-property Firms before and after Asian Financial Crisis

\begin{tabular}{|c|c|c|c|c|c|c|c|}
\hline \multicolumn{4}{|c|}{ PRE-CRISIS 1992 TO $1996(\mathrm{n}=58)$} & \multicolumn{4}{|c|}{ POST-CRISIS 1997 TO $2001(\mathrm{n}=70)$} \\
\hline Days & Average & t-test & CAR & & Average & t-test & CAR \\
\hline & Returns & & & & Returns & & \\
\hline-50 & -0.000494 & -0.1325 & -0.000494 & -50 & -0.002898 & -0.6357 & -0.002898 \\
\hline-49 & 0.000177 & 0.0486 & -0.000317 & -49 & 0.001933 & 0.3423 & -0.000965 \\
\hline-48 & -0.001764 & -0.3254 & -0.002082 & -48 & -0.005496 & -0.8212 & -0.006461 \\
\hline-47 & -0.007309 & -1.8356 & -0.009391 & -47 & -0.006222 & -1.0198 & -0.012683 \\
\hline-46 & 0.000192 & 0.0500 & -0.009199 & -46 & -0.004249 & -0.7567 & -0.016932 \\
\hline-45 & 0.005989 & 1.4666 & -0.003210 & -45 & 0.007840 & 1.5429 & -0.009092 \\
\hline-44 & 0.004093 & 0.6738 & 0.000883 & -44 & 0.000937 & 0.1678 & -0.008156 \\
\hline-43 & 0.003042 & 0.7119 & 0.003924 & -43 & -0.008671 & -1.5415 & -0.016827 \\
\hline-42 & 0.000908 & 0.2333 & 0.004832 & -42 & -0.006427 & -1.1618 & -0.023253 \\
\hline-41 & 0.004705 & 1.4208 & 0.009537 & -41 & -0.005909 & -1.1853 & -0.029162 \\
\hline-40 & -0.009067 & $-2.4909 *$ & 0.000470 & -40 & 0.005147 & 0.9411 & -0.024015 \\
\hline-39 & 0.002014 & 0.6091 & 0.002484 & -39 & 0.000532 & 0.0970 & -0.023483 \\
\hline-38 & -0.005181 & -1.5631 & -0.002697 & -38 & -0.000394 & -0.0866 & -0.023877 \\
\hline-37 & 0.003053 & 0.8780 & 0.000356 & -37 & -0.001626 & -0.3153 & -0.025503 \\
\hline-36 & -0.000107 & -0.0327 & 0.000249 & -36 & -0.001835 & -0.2838 & -0.027339 \\
\hline-35 & -0.001045 & -0.3128 & -0.000796 & -35 & -0.011841 & $-2.2997 *$ & -0.039179 \\
\hline-34 & 0.004975 & 1.0825 & 0.004179 & -34 & -0.000897 & -0.1843 & -0.040076 \\
\hline-33 & 0.004149 & 0.6623 & 0.008328 & -33 & 0.000327 & 0.0808 & -0.039749 \\
\hline-32 & 0.002912 & 0.7444 & 0.011240 & -32 & -0.008397 & $-2.0213^{*}$ & -0.048146 \\
\hline-31 & -0.006634 & -1.9182 & 0.004605 & -31 & 0.002355 & 0.5470 & -0.045791 \\
\hline-30 & 0.002874 & 0.7574 & 0.007480 & -30 & -0.000958 & -0.2042 & -0.046749 \\
\hline-29 & 0.000464 & 0.1672 & 0.007944 & -29 & -0.012325 & $-2.3952 *$ & -0.059073 \\
\hline-28 & -0.000109 & -0.0341 & 0.007835 & -28 & 0.000906 & 0.1728 & -0.058167 \\
\hline-27 & -0.002419 & -0.7386 & 0.005416 & -27 & -0.005046 & -1.0373 & -0.063214 \\
\hline-26 & -0.005423 & -1.4815 & -0.000007 & -26 & -0.010832 & $-2.3066^{*}$ & -0.074046 \\
\hline-25 & 0.005873 & 1.2371 & 0.005866 & -25 & 0.002740 & 0.6437 & -0.071305 \\
\hline
\end{tabular}




\begin{tabular}{|c|c|c|c|c|c|c|c|}
\hline-24 & 0.004686 & 1.3920 & 0.010552 & -24 & -0.013523 & $-3.0002 * *$ & -0.084828 \\
\hline-23 & -0.003163 & -0.8215 & 0.007390 & -23 & 0.002680 & 0.6651 & -0.082148 \\
\hline-22 & 0.001125 & 0.1589 & 0.008515 & -22 & 0.001446 & 0.2565 & -0.080702 \\
\hline-21 & 0.001227 & 0.4279 & 0.009742 & -21 & -0.002394 & -0.3267 & -0.083096 \\
\hline-20 & -0.001917 & -0.5985 & 0.007825 & -20 & -0.009471 & -1.4976 & -0.092568 \\
\hline-19 & 0.001256 & 0.2743 & 0.009082 & -19 & -0.007965 & -1.5223 & -0.100533 \\
\hline-18 & -0.001615 & -0.4662 & 0.007467 & -18 & -0.005023 & -1.1172 & -0.105556 \\
\hline-17 & -0.006818 & $-2.0210^{*}$ & 0.000649 & -17 & -0.003955 & -0.5628 & -0.109511 \\
\hline-16 & 0.000640 & 0.2396 & 0.001289 & -16 & -0.006567 & -0.9098 & -0.116078 \\
\hline-15 & -0.000895 & -0.2668 & 0.000394 & -15 & -0.000112 & -0.0193 & -0.116189 \\
\hline-14 & 0.005691 & 1.2342 & 0.006085 & -14 & -0.007000 & -1.0673 & -0.123189 \\
\hline-13 & -0.004354 & -1.4276 & 0.001731 & -13 & -0.000751 & -0.1071 & -0.123940 \\
\hline-12 & -0.001635 & -0.4265 & 0.000096 & -12 & 0.003069 & 0.8864 & -0.120871 \\
\hline-11 & 0.000292 & 0.0860 & 0.000388 & -11 & 0.003645 & 0.6208 & -0.117226 \\
\hline-10 & -0.003632 & -1.2695 & -0.003244 & -10 & -0.003167 & -0.9866 & -0.120393 \\
\hline-9 & 0.003029 & 0.7967 & -0.000215 & -9 & -0.002505 & -0.7129 & -0.122898 \\
\hline-8 & -0.002880 & -0.7527 & -0.003094 & -8 & -0.004097 & -1.1030 & -0.126995 \\
\hline-7 & -0.004886 & -1.2352 & -0.007980 & -7 & -0.001345 & -0.3786 & -0.128340 \\
\hline-6 & 0.008050 & $1.9706^{*}$ & 0.000069 & -6 & 0.002283 & 0.4896 & -0.126057 \\
\hline-5 & 0.000962 & 0.1570 & 0.001032 & -5 & -0.009492 & $-2.5599 *$ & -0.135549 \\
\hline-4 & 0.002085 & 0.6871 & 0.003116 & -4 & -0.009336 & -1.6014 & -0.144885 \\
\hline-3 & -0.003628 & -1.1573 & -0.000512 & -3 & 0.004767 & 0.9271 & -0.140118 \\
\hline-2 & 0.001372 & 0.4317 & 0.000860 & -2 & 0.000350 & 0.0632 & -0.139768 \\
\hline-1 & 0.006008 & 1.6176 & 0.006868 & -1 & 0.002799 & 0.3265 & -0.136969 \\
\hline 0 & 0.004988 & 0.5448 & 0.011856 & 0 & -0.005047 & -0.7645 & -0.142016 \\
\hline 1 & -0.003405 & -1.1126 & 0.008451 & 1 & 0.005358 & 0.9834 & -0.136658 \\
\hline 2 & -0.005881 & -1.7511 & 0.002570 & 2 & 0.001227 & 0.2353 & -0.135431 \\
\hline 3 & 0.005764 & 1.3522 & 0.008334 & 3 & -0.005980 & -1.1801 & -0.141411 \\
\hline 4 & 0.003069 & 0.6989 & 0.011404 & 4 & -0.007697 & -1.8800 & -0.149107 \\
\hline 5 & 0.010514 & 1.9218 & 0.021917 & 5 & -0.006128 & -1.6352 & -0.155235 \\
\hline 6 & -0.001680 & -0.4358 & 0.020237 & 6 & 0.008310 & 1.4594 & -0.146925 \\
\hline 7 & 0.002687 & 0.7875 & 0.022924 & 7 & -0.009089 & -1.5430 & -0.156014 \\
\hline 8 & -0.003524 & -0.9037 & 0.019400 & 8 & 0.000317 & 0.0572 & -0.155697 \\
\hline 9 & 0.002128 & 0.5246 & 0.021528 & 9 & 0.002827 & 0.5373 & -0.152870 \\
\hline 10 & -0.004170 & -1.2528 & 0.017357 & 10 & -0.001044 & -0.2102 & -0.153914 \\
\hline
\end{tabular}




\begin{tabular}{rrrr|rrrr}
11 & -0.004830 & -1.2419 & 0.012527 & 11 & -0.004520 & -0.9262 & -0.158433 \\
12 & -0.005286 & -1.2438 & 0.007241 & 12 & 0.010001 & 1.8260 & -0.148432 \\
13 & 0.002576 & 0.6718 & 0.009817 & 13 & -0.001524 & -0.4023 & -0.149956 \\
14 & 0.000640 & 0.0990 & 0.010458 & 14 & -0.000385 & -0.1122 & -0.150341 \\
15 & 0.001920 & 0.4734 & 0.012378 & 15 & 0.010315 & $2.7077 * *$ & -0.140026 \\
16 & -0.006472 & $-2.0312 *$ & 0.005905 & 16 & 0.014945 & $2.1587 *$ & -0.125081 \\
17 & 0.002779 & 0.5787 & 0.008685 & 17 & -0.006586 & -1.3502 & -0.131667 \\
18 & 0.001031 & 0.2542 & 0.009715 & 18 & 0.005893 & 1.1046 & -0.125774 \\
19 & -0.001222 & -0.3730 & 0.008494 & 19 & 0.003323 & 0.5747 & -0.122451 \\
20 & -0.001876 & -0.6409 & 0.006618 & 20 & -0.001797 & -0.3160 & -0.124248 \\
21 & 0.002933 & 0.8528 & 0.009550 & 21 & -0.001772 & -0.4403 & -0.126020 \\
22 & -0.003694 & -0.9054 & 0.005856 & 22 & -0.003267 & -0.7091 & -0.129287 \\
23 & 0.002666 & 0.5647 & 0.008521 & 23 & -0.012689 & $-2.5604 *$ & -0.141976 \\
24 & 0.007253 & 1.0749 & 0.015775 & 24 & -0.005846 & -1.1426 & -0.147822 \\
25 & 0.000779 & 0.2031 & 0.016554 & 25 & 0.001427 & 0.4275 & -0.146394 \\
26 & -0.007215 & $-2.1545 *$ & 0.009339 & 26 & -0.000292 & -0.0625 & -0.146687 \\
27 & -0.004313 & -1.1638 & 0.005026 & 27 & 0.005633 & 1.3723 & -0.141053 \\
28 & 0.008473 & $2.2213 *$ & 0.013499 & 28 & -0.003650 & -0.7454 & -0.144703 \\
29 & -0.000394 & -0.1004 & 0.013105 & 29 & 0.001648 & 0.3150 & -0.143055 \\
30 & 0.000302 & 0.0701 & 0.013407 & 30 & -0.007448 & -1.2689 & -0.150503 \\
\hline
\end{tabular}

Note : Significant at $0.05\left(^{*}\right)$ and $0.01(* *)$ level.

\section{Revaluation effect of property disposals during the recession period (1997-2001)}

Table 7 shows investors respond negatively to announcements of property disposals during the recession period. The day zero average abnormal return is $-0.5 \%$, but is statistically insignificant at any level. The ARs on day -35 , day -32 , day -29 , day -26 and day -5 are significantly different from zero at 0.05 level whilst day -24 is significantly different from zero at 0.01 level. After the announcement date, day 15 is significantly different from zero at the 0.01 level. Day 16 and day 23 are significantly different from zero at the 0.05 level.

The market reaction seems to have started as far back as 35 days prior to the announcement day. Information leakage appeared to have occurred prior to the announcement date. Property disposals require a lengthy period of negotiation, and buyers and sellers and the process involves many parties (e.g. valuers, estate agents, merchant bankers, lawyers, accountants etc.), hence the possibility of information leakage. 
On the announcement date, the CAR is a loss of $14.2 \%$ to shareholders. The magnitude of loss is large and is contrary to conventional wisdom that sell-offs are significantly positive to shareholders wealth. Studies by Owers and Rogers (1986), Jain (1985) and Glascock, Davidson and Sirmans (1991) have shown that property disposals are positive corporate actions that bring forth positive price reactions.

Figure 2 presents the plot of CAR around the property disposal announcement day. Overall, the cumulative abnormal returns for the recession period have negative values and the figure shows a negative trending CAR, unlike the buoyant period.

\section{Figure 2: Plot of Cumulative Abnormal Returns Around Property Disposal Announcements on Bursa Malaysia from 1992 to 1996}

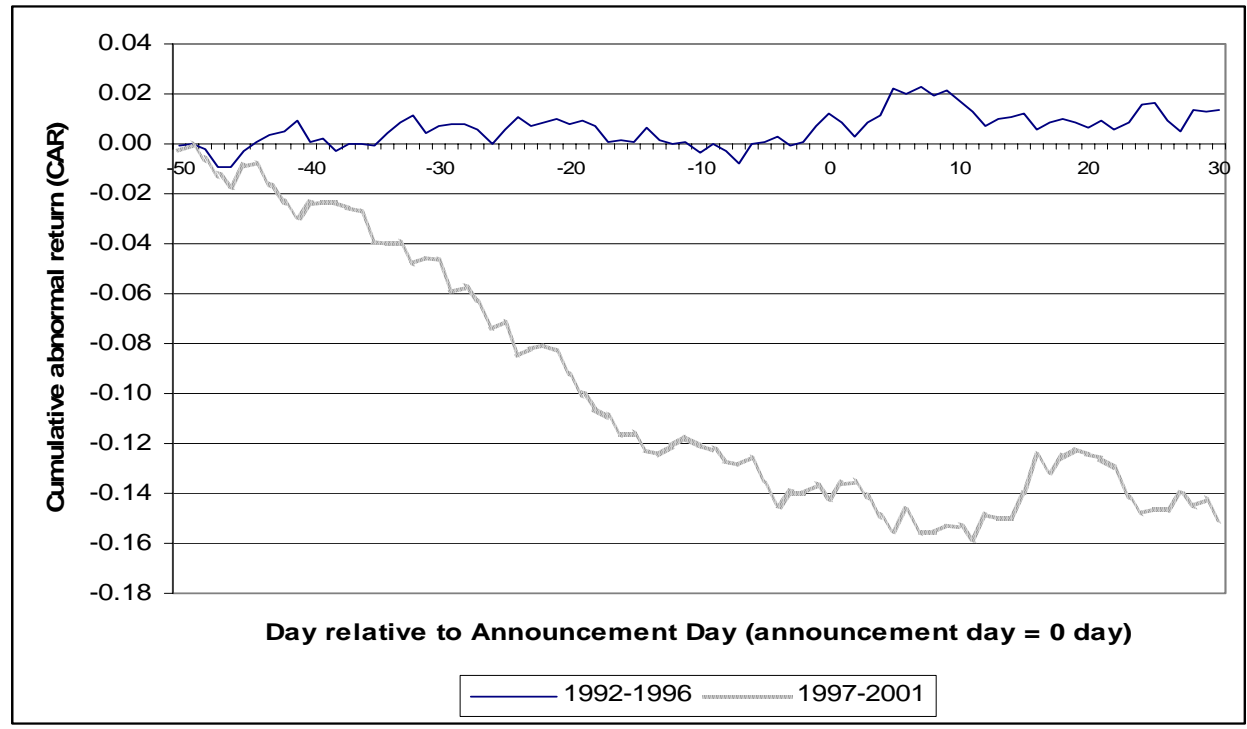

Table 8 shows the CAR over different cumulative periods. The CARs for window ( -1 , +1 ) for both periods are significant at the 0.001 level. For the crisis period, the CARs before the announcement day are negative and are statistically significantly at 0.05 level for the window $(-40,+1)$ and 0.01 level for $(-30,+1),(-20,+1)$ and $(-10,+1),(-5,+1)$. For the post announcement day period, the CARs are also negative and are statistically significant at the 0.001 level.

Table 8 shows the contrasting CAR values for different economic periods. The CARs for the recession period for the before, on and after announcement day is negative and are 
statistically significant. In contrast, the CARs for the buoyant period are positive and are statistically significant only on and after the announcement day. The CARs are negative and substantially large during the recession period compared to smaller positive CARs at the buoyant period.

Table 8: Test of Significance on Cumulative Abnormal Returns for Property Disposal Announcements over Different Cumulative Periods

\begin{tabular}{|c|c|c|c|c|c|c|}
\hline Periods & Average CAR & & & verage CAR & & \\
\hline & (1992-1996) & t-test & & $(1997-2001)$ & t-test & \\
\hline $\operatorname{CAR}(-50,+1)$ & 0.002805 & 0.548766 & & -0.074870 & -1.570188 & \\
\hline $\operatorname{CAR}(-40,+1)$ & 0.003604 & 0.778982 & & -0.089686 & -2.213851 & * \\
\hline $\operatorname{CAR}(-30,+1)$ & 0.003842 & 0.807473 & & -0.107176 & -3.751102 & $* * *$ \\
\hline $\operatorname{CAR}(-20,+1)$ & 0.002373 & 0.500224 & & -0.123923 & -8.927884 & $* * *$ \\
\hline $\operatorname{CAR}(-10,+1)$ & 0.001434 & 0.261783 & & -0.133387 & 16.489245 & $* * *$ \\
\hline $\operatorname{CAR}(-5,+1)$ & 0.004525 & 0.980992 & & -0.139423 & 42.089955 & $* * *$ \\
\hline $\mathrm{CAR}(-2,+2)$ & 0.006121 & 1.375984 & & -0.138168 & 51.695044 & $* * *$ \\
\hline CAR $(-1,+1)$ & 0.009059 & 3.554175 & $* * *$ & -0.138548 & 46.066438 & $* * *$ \\
\hline $\mathrm{CAR}(+2,+5)$ & 0.011056 & 1.362667 & & -0.145296 & 16.750048 & $* * *$ \\
\hline $\operatorname{CAR}(+2,+10)$ & 0.016186 & 2.275412 & $*$ & -0.149623 & 20.784123 & $* * *$ \\
\hline $\operatorname{CAR}(+2,+20)$ & 0.012500 & 2.030005 & $*$ & -0.143317 & 11.687951 & $* * *$ \\
\hline $\operatorname{CAR}(+2,+30)$ & 0.012005 & 2.192691 & * & -0.142776 & 13.160394 & $* * *$ \\
\hline
\end{tabular}

Note : Significant at $0.05(*)$ and $0.001(* * *)$ levels.

A t-test is carried out to determine any mean differences between the average abnormal returns of the two economic periods. The t-test shows that the mean difference of the average abnormal returns is significantly different at the 0.05 level. 
Table 9: T-test on average abnormal returns of property disposals over the window period $(-50,+30)$ for the $1992-1996$ and $1997-2001$ period

\begin{tabular}{lll}
\hline & Average AR & Average AR \\
& $1992-1996$ & $1997-2001$ \\
\hline Mean & 0.000166 & -0.001858 \\
Observations & 81 & 81 \\
Hypothesized mean diff & 0 & \\
df & 147 & \\
t-stat & $2.6022 *$ & \\
\hline
\end{tabular}

Note : Significant at $0.05\left(^{*}\right)$ level.

A t-test is also carried out to test the differences of the CARs between the two economic periods. The t-test shows that the CARs of the two periods are significantly different from zero at the 0.05 level for the CAR window $(-10,+1)$ and at 0.001 level for the CAR window period of $(-5,+1)$ CAR $(-2,+2)$ CAR $(-1,+1)$ CAR $(+2,+5)$ and $\operatorname{CAR}(+2,+10)$.

\section{Source of gains in property disposals}

Table 11 provides summary statistics using regression of the CARs on the economic condition as a dummy variable 1 for recession and 0 for buoyant period. The relative size, expressed as relative value of the property disposed to the size of the market capitalization of the firm, is included as a control variable.

For the Industrial Sector, the F-ratio of 2.92 in the regression is statistically significant at the 0.05 level. The regression model explains 14.33 percent of the variation in the dependent variable. The results show that the economic conditions have a coefficient of 0.0404 with t-statistic of 2.364 . The coefficient of the economic condition is positive (0.0404) and statistically significant at 0.05 level. Therefore the coefficient is significantly different from zero at 0.05 level. The low $\mathrm{R}^{2}$ value could be due to noise in the data; especially the CARs during the crisis period.

For relative size of property disposal, the results show that the independent variable is statistically significant for the full sample, Main Board companies, Plantation and Construction Sectors. The coefficients of the size variable are significant at 0.05 level for Main Board and Construction Sector, 0.01 level for the full sample and 0.001 for the Plantation Sector. 
Table 10: T-tests on average CAR over selected window intervals of property disposals

\begin{tabular}{lrcll}
\hline & $\begin{array}{r}\text { Average CAR } \\
1992-1996\end{array}$ & $\begin{array}{c}\text { Average CAR } \\
1997-2001\end{array}$ & Difference & t-stats \\
\hline CAR $(-50,+1)$ & 0.00280 & -0.07487 & 0.07767 & 0.06291 \\
CAR $(-40,+1)$ & 0.00360 & -0.08969 & 0.09329 & 0.11027 \\
CAR(-30,+1) & 0.00384 & -0.10718 & 0.11102 & 0.24338 \\
CAR(-20,+1) & 0.00237 & -0.12392 & 0.12630 & 0.80113 \\
CAR(-10,+1) & 0.00143 & -0.13339 & 0.13482 & $2.40226^{*}$ \\
CAR(-5,+1) & 0.00452 & -0.13942 & 0.14395 & $7.82297^{* * *}$ \\
CAR(-2,+2) & 0.00612 & -0.13817 & 0.14429 & $12.43356^{* * *}$ \\
CAR(-1,+1) & 0.00906 & -0.13855 & 0.14761 & $30.57123^{* * *}$ \\
CAR(+2,+5) & 0.01106 & -0.14530 & 0.15635 & $7.60000^{* * *}$ \\
CAR $(+2,+10)$ & 0.01619 & -0.14962 & 0.16581 & $3.86164 * * *$ \\
CAR(+2,+20) & 0.01250 & -0.14332 & 0.15582 & 1.22811 \\
CAR $(+2,+30)$ & 0.01200 & -0.14278 & 0.15478 & 0.89396 \\
\hline
\end{tabular}

Note : Significant at $0.05(*)$ and $0.001(* * *)$ levels.

Further analysis on the CARs is carried out to examine the effect of economic conditions, disposal gain/loss and the impact of related transactions. Table 12 shows the regression results of the cumulative average abnormal returns on disposal gain/loss and the relatedness of the transaction. Both variables use a dummy variable.

The results show that the GAIN and RELATED variables are statistically insignificant at any level. But the economic condition is statistically significant at the 0.01 level for Regression 1 and 0.001 level for Regression 2 and 3. The F-ratios are also statistically significant for Regression 1 at 0.01 level and Regression 2 and 3 at the 0.001 level. The regression models explain 5 to 13.9 percent of the variation in the dependent variable. 
Table 11: Regression analysis of CARs on economic conditions and size of disposal. Regression equation: $\mathrm{CAR}_{i t}=\mathrm{a}_{1}+\mathrm{a}_{2} \mathrm{ECON}_{\mathrm{it}}+\mathrm{SIZE}_{\mathrm{it}}+\mathrm{e}_{\mathrm{it}}$

\begin{tabular}{lccccc}
\hline Regression & $\begin{array}{c}\text { Full } \\
\text { Sample }\end{array}$ & $\begin{array}{c}\text { Main } \\
\text { Board }\end{array}$ & $\begin{array}{c}\text { Plantation } \\
\text { Sector }\end{array}$ & $\begin{array}{c}\text { Industrial } \\
\text { Sector }\end{array}$ & $\begin{array}{c}\text { Construction } \\
\text { Sector }\end{array}$ \\
\hline Intercept & -0.0017 & 0.0053 & -0.0524 & -0.0273 & 0.0647 \\
ECON & -0.0140 & -0.0251 & -0.0312 & 0.0404 & -0.0611 \\
& $(-0.972)$ & $(-1.433)$ & $(-0.878)$ & $(2.364)^{*}$ & $(-1.131)$ \\
SIZE & 0.0012 & 0.0012 & 0.0064 & -0.0002 & 0.0033 \\
n & $\left(2.642^{* *}\right)$ & $\left(2.352^{*}\right)$ & $\left(\begin{array}{c}\left.5.398^{* * *}\right) \\
(-0.468)\end{array}\right.$ & $\begin{array}{c}\left(2.246^{* *}\right) \\
16\end{array}$ \\
Adj. R-sq & 117 & 85 & 28 & 24 & 0.2096 \\
F-stat & 0.0424 & 0.0489 & 0.6242 & 0.1433 & \\
& & & & & \\
\hline
\end{tabular}

Note : Significant at $0.05(*), 0.01(* *)$ and $0.001(* * *)$ levels.

Table 12: Regression analysis of CARs on economic conditions and size of disposal. Regression equation: CAR $_{\text {it }}=a_{1}+a_{2}$ ECON $_{i t}+a_{3}$ GAIN $_{i t}+$ RELATED $_{i t}+e_{i t}$

\begin{tabular}{lccc}
\hline Regression & 1 & 2 & 3 \\
\hline Intercept & -0.0167 & -0.0336 & -0.0336 \\
ECON & 0.0249 & 0.0433 & 0.04291 \\
GAIN & -0.001 & -0.0018 & \\
RELATED & $(-0.068)$ & $-0.112)$ & 0.0221 \\
n & & 0.0221 & $(1.3874)$ \\
Adj. R-sq & 65 & 50 & 50 \\
F-stat & 0.0506 & 0.1209 & 0.1394 \\
& $2.70^{* *}$ & $3.25^{* *}$ & $4.97 * *$
\end{tabular}

Note : Significant at $0.05(*), 0.01(* *)$ and $0.001(* * *)$ levels. 


\section{DISCUSSION}

The stock price reaction which is significant and positive to property disposal announcements for the pre-crisis period is consistent with the findings of earlier studies. However, for the post crisis period, the valuation effect is negative for the shareholders wealth.

In other words, non-property firms that sell properties during the normal market conditions are positive net present value (NPV) transactions that create value for the shareholders. Real estate restructurings such as property disposals give rise to wealth changes through signals about changes in expectations for future cash flows and the value of the firm. Christensen and Levi (1993) find a positive unexpected change in cash flows for firms that sell properties. Also, sellers do not experience change in the total firm risk. The announcement of the sale of real estate sends a signal that on average cash flow will improve in the near term. The improvement in cash flow could arise from the sale of surplus properties or properties that are not synergistic with the operations of the firm.

On the other hand, the Asian Financial Crisis has changed the fundamental parameters of a positive business environment and property market. During the crisis, investors' expectations on the profitability of firms are negatively impacted by poor economic conditions, tight fiscal and monetary policies. The worsen property market affects the availability of industry buyers. Investors view property disposals as an attempt to improve liquidity and cash-flows and a negative NPV transaction. Hence any property disposals made during the crisis period is met with negative share price reactions.

\section{CONCLUSION}

This study examines the price effects around announcements of property disposals by non-property companies over a ten year period. It also investigates whether economic conditions affect the valuation effects of property disposals.

The results show different price effects when firms announce property disposals during a buoyant and recession economic period. For the buoyant period, the results show a significantly positive response to the announcements of property disposals. But a significantly negative price effect is obtained for property disposals announced during the recession period. This finding adds to the literature because no previous study has examined the price effects of property disposals under different economic conditions. The result is supported by findings from event studies and cross-sectional regressions. 
The results also show that the CARs are affected by the relative size of the disposal. Larger relative disposal would elicit a higher price response. The positive price effect is consistent with studies on other types of corporate disposals.

Further research could be carried out to examine the impact of interest rates, stock market volatility, property market return etc. on the abnormal returns during the recession period.

The implications of this study to decision makers is that firms planning to dispose of properties should take advantage of favourable economic conditions, as market reaction is more positive at such times. Investors may expect positive stock valuations during buoyant market and negative stock reactions during crisis/recession period with respect to property disposal announcements.

\section{REFERENCES}

Alexander, G. J., Benson, P. G. and Kampmeyer, J. M. (1984). Investigating the valuation effects of announcements of voluntary corporate sell-offs. Journal of Finance, 39 , pp. 503-517.

Annuar, M. N., Ariff, M., and Shamsher, M. (1994). Is Kuala Lumpur's emerging share market efficient? Journal of International Financial Markets, Institutions and Money, 4(2), pp. 89-100.

Ariff, M. and Johnson, L. W. (1990). Securities markets and stock pricing: Evidence from a developing capital market in Asia. Singapore: Longman.

Ball, J'Noel, Rutherford, R. C. and Shaw, R. (1993). The wealth effects of real estate spin-offs. Journal of Real Estate Research, 8(4), pp. 597-606.

Baum, A. (1983). Statutory Valuations, London, Routledge \& Kegan Paul.

Baum, A., Mackmin, D. and Nunnington, N. (1983). The income approach to property valuation. London, International Thomson Business Press.

Booth, G.G., Glascock, J.L. and Sarkar, S.K. (1996). A reexamination of corporate selloffs of real estate assets. Journal of Real Estate Finance and Economics, 12, pp. 195-202.

Boudreaux, K. J. (1975). Divestiture and share price. Journal of Financial and Quantitative Analysis, 10, pp. 619-626.

Brown, R. K. et al. (1993). Managing corporate real estate, New York, John Wiley \& 
Sons, Inc.

Cheng, F. F. (2000). The impact of accounting earnings disclosures on stock prices in Malaysia; an emerging market. Unpublished Ph.D. thesis, Universiti Putra Malaysia, Serdang, Malaysia.

Christensen, D. G. and Levi, D. R. (1993). Corporate restructurings involving real estate assets: Some earnings and risk signal implications. Journal of Real Estate Research, 8(4), pp. 579-595.

Dranikoff, Lee, Koller, T. and Schneider, A. (2002). Divestiture : Strategy's missing link. Harvard Business Review, May, pp. 75-83.

Elayan, Fayez and Maris, Brian E. (1991). Stock market response to voluntary liquidations and reorganisation of real estate corporations. AREUEA Journal 19(1), pp. 92-101.

Elayan, Fayez and Young, Philip (1994). The value of control : Evidence from full and partial acquisitions in the real estate industry. Journal of Real Estate Finance and Economics, 8(2), pp. 167-182.

Fisher, D. (2000). Indonesia's real estate disturbance. In Mera, K. and Renaud, B. ed. Asia's Financial crisis and the role of real estate. New York, M.E. Sharpe.

Fowler, D. and Rorke, C. (1983). Risk measurement when shares are subject to infrequent trading: comment. Journal of Financial Economics, 12(3), 279-283.

Gertner, R. and Scharfstein, S. (1991). A theory of workouts and the effects of reorganization law. Journal of Finance, 46, pp. 1189-1222

Giroux, B. P. (1987). Asset disposition in Silverman, R. A. ed. Corporate Real Estate Handbook McGraw-Hill Book Co., New York

Glascock, John, Davidson, Wallace and Sirmans, C. F. (1989). An analysis of the acquisition and disposition of real estate assets. Journal of Real Estate Research, 4(3), pp. 131-140.

Glascock, John, Davidson, Wallace and Sirmans, C.F.(1991). The gains from corporate selloffs : The case of real estate assets. AREUEA Journal, 19(4), pp. 567-582.

Hearth, D. and Zaima, J. K. (1984). Voluntary corporate divestiture and value. Financial Management, 13, pp. 10-16. 
Hite, G. L. and Owers, J. E. (1983). Security price reactions around corporate spin-off announcements. Journal of Financial Economics, 12, pp. 409-436.

Jain, P. C. (1985). The effect of voluntary sell-off announcements on shareholder wealth. Journal of Finance, 40, pp. 209-224.

Jensen, Michael C, and Meckling, William. (1976). Theory of the firm : Managerial Behaviour, agency costs and ownership structure. Journal of Financial Economics, 3(4), pp. $305-360$.

John, K. and Ofek, E. (1995). Asset sales and increase in focus. Journal of Financial Economics, 37(1), pp. 105-126.

Kallberg, J. G. Liu, C. H. and Pasquariello, P. (2002). Regime shifts in Asian equity and real estate markets. Real Estate Economics, 30(2), pp. 263-291.

Klein, A. (1986). The timing and substance of divestiture announcements : individual, simultaneous and cumulative effects. Journal of Finance, 41, pp. 685-696.

Linn, S. C. and Rozeff, M. S. (1984). The corporate sell-off. Midland Corporate Finance Journal, 2, Summer, pp. 17-26.

Liow, Kim Hiang. (1997). The pricing of Corporate real estate in the UK stock market. Journal of Real Estate and Construction, 7, pp. 1-8.

Liow, Kim Hiang and Ooi, J. T. L. (2004). Does corporate real estate create wealth for shareholders. Journal of Property Investment and Finance, 22(5), pp. 386-400.

Maroney, N., Naka, A. and Wansi, T. (2004). Changing risk, return and leverage: The 1997 Asian Financial Crisis. Journal of Financial and Quantitative Analysis, 39(1), pp. 143-166.

Mera, K. and Renaud, B. ed. (2000). Asia's Financial Crisis and the role of real estate. New York, M. E. Sharpe.

McIntosh, Willard, Ott, Steven and Liang, Youguo. (1995). The wealth effects of Real estate transactions : The case of REITs. Journal of Real Estate Finance and Economics, 10, pp. 299-306.

Miles, J. A. and Rosenfeld, J. D. (1983). The effect of voluntary spin-off announcements on shareholder wealth. Journal of Finance, 38, pp. 1597-1606.

Myer, F C, He, Ling, and Webb, James. (1992). Sell-offs of U.S.real estate: The effect of 
domestic versus foreign buyers of shareholder wealth. AREUEA Journal, 20(3), pp. 487-500.

Myers, S. C. and Majluf, N. (1984). Corporate financing and investment decisions when firms have information that investors do not have. Journal of Financial Economics, 13, pp. 187-221.

Owers, J. E. and Rogers, R. C. (1986). The divestiture of real estate assets by sell-off. Real Estate Issues, 11(1), pp. 29-35.

Renaud, B. (2003). Speculative behaviour in immature real estate markets, lessons of the 1997 Asia Financial Crisis. Urban Policy and Research, 21(2), pp. 153-173.

Rodriquez, M. and Sirmans, C. F. (1996). Managing corporate real estate: Evidence for the capital markets. Journal of Real Estate Literature, 4, pp. 13-33.

Schipper, K. and Smith, A. (1983). Effects of recontracting on shareholder wealth: The case of voluntary spin-offs. Journal of Financial Economics, 12, pp. 437-468.

Schipper, K. and Smith, A. (1986). A comparison of equity carve-outs and equity offerings:Share price effects and corporate restructuring. Journal of Financial Economics, 15 , pp. 153-186.

Sicherman, N.,W. and Pettway, R. H. (1992). Wealth effects for buyers and sellers of the same divested assets. Financial Management, 21, pp. 119-128.

Ting, Kien Hwa. (2004). Corporate real estate investment and ownership: Empirical evidence from Bursa Malaysia Listed Companies. Unpublished research report for Universiti Teknologi MARA with grant support of Real Estate Research and Development Grant Scheme (NAPREC), Valuation \& Property Services Department, Ministry of Finance, Malaysia.

Wang, K., Zhou, Y., Chan, S.H. and Chau, K.W. (2000). Over confidence and cycles in real estate markets: Cases in Hong Kong and in Asia. International Real Estate Review, 3(1), pp. 93-106.

Zaima, J. K. and Hearth, D. (1985). The wealth effects of voluntary selloffs: Implications for divesting and acquiring firms. Journal of Financial Research, 8, pp. 227-236.

Zeckhauser, Sally and Silverman, Robert. (1983). Rediscover your company's real estate. Harvard Business Review, 6(1), pp. 111-117. 